\title{
Analisis Pendapatan Negara Indonesia Kota Bogor Provinsi Jawa Barat Dengan Metode Kuantitatif
}

\author{
Renita Millena \\ Universitas Internasional Batam \\ millena.renita@gmail.com
}

\section{Tia Jesi}

Universitas Internasional Batam jesithia01@gmail.com

\begin{abstract}
Abstrak Tujuan dari penelitian ini adalah untuk mengetahui pendapatan nasional bruto dan pertumbuhan ekonomi Kota Bogor. Pendekatan penelitian ini adalah kuantitatif karena proses datanya berupa bilangan. Studi ini juga mengidentifikasi dampak virus corona terhadap pendapatan nasional bruto kota Bogor. Hasil penelitian menunjukkan pendapatan nasional bruto Bogor semakin meningkat dari waktu ke waktu. Kinerja pemerintah kota bogor tidak stabil. Semua itu dapat diindikasikan dengan masih tingginya ketergantungan situasi keuangan pada pemerintah pusat yang pendapatannya perkapita. Pajak daerah memiliki pengaruh yang sangat positif. Sedangkan GDRP berpengaruh negatif terhadap kinerja keuangan. Dengan hal tersebut, tentunya peneliti juga ingin menerapkan strategi dalam rangka meningkatkan efektifitas dan efisiensi kinerja keuangan yang sangat baik seperti peningkatan proses pendidikan, proses supervisi dan pelatihan serta komunikasi atau komitmen lain untuk mencapai tujuan.

Kata Kunci Pendapatan Nasional, Pertumbuhan, Keuangan, Pendapatan Perkapita, Pajak Daerah.

\section{PENDAHULUAN}

Bogor bisa dikatakan sebagai salah satu kota yang ada di Indonesia yang mana kaya akan keragaman budayanya. Kota ini dikenal juga dengan sebutan kota hujan mengingat kota inilah memiliki curah hujan yang lebih tinggi dibandingkan kota lainnya. Kota ini merupakan salah satu pusat dari negara Indonesia dan termasuk kedalam istilah jabodetabek. Tujuan dari penelitian ini adalah untuk meneliti pendapatan asli daerah kota bogor. Penulis ingin meneliti seberapa buruk dampak virus corona terhadap pendapatan daerah kota bogor mengingat kota ini merupakan salah satu destinasi favorit wisatawan lokal. Berikut adalah tabel pendapatan kota bogor menurut jenis pendapatan.
\end{abstract}


Tabel 1 Pendapatan Nasional Kota Bogor

\begin{tabular}{|c|c|c|c|c|}
\hline \multirow{2}{*}{\multicolumn{5}{|c|}{$\begin{array}{c}\text { Realisasi Penerimaan Pemerintah Kota Bogor Menurut Jenis Pendapatan, 2014-20 } \\
\text { Actual Receipt of Government of Bogro City by Receipt Items, 2014-2015 }\end{array}$}} \\
\hline & & & & \\
\hline \multirow[t]{2}{*}{ Jenis Penerimaan } & \multirow[b]{2}{*}{$\begin{array}{l}2014 \\
\text { (Juta/ } \\
\text { Million } \\
\text { Rp) }\end{array}$} & \multirow[b]{2}{*}{$\begin{array}{l}2015 \\
\text { (Juta/ } \\
\text { Million } \\
\text { Rp) }\end{array}$} & \multirow[b]{2}{*}{$\begin{array}{l}2016 \\
\text { (Juta/ } \\
\text { Million } \\
\text { Rp) }\end{array}$} & \multirow[b]{2}{*}{$\begin{array}{l}\text { Kena } \\
\text { ikan } \\
2016 \\
\text { terha } \\
\text { dap } \\
2015 \\
(\%)\end{array}$} \\
\hline & & & & \\
\hline \multicolumn{5}{|l|}{$\begin{array}{l}\text { A. PENDAPATAN DAERAH/LOCAL } \\
\text { GOVERNMENT REVENUE }\end{array}$} \\
\hline $\begin{array}{l}\text { 1. Pendapatan Asli Daerah/Original Local Government } \\
\text { Revenue }\end{array}$ & \begin{tabular}{|l|}
544 \\
835.70 \\
\end{tabular} & $\begin{array}{l}627 \\
597.05\end{array}$ & $\begin{array}{l}681 \\
623.90\end{array}$ & 8.61 \\
\hline 1.1. Pendapatan Pajak Daerah/Local Taxes & \begin{tabular}{|l|}
376 \\
487.55 \\
\end{tabular} & $\begin{array}{l}398 \\
435.40\end{array}$ & $\begin{array}{l}447 \\
951.03\end{array}$ & $\begin{array}{l}12.4 \\
3\end{array}$ \\
\hline 1.2. Hasil Retribusi daerah/Local Retributions & \begin{tabular}{|l|}
77 \\
167.65
\end{tabular} & $\begin{array}{l}46 \\
219.89\end{array}$ & $\begin{array}{l}56 \\
982.63\end{array}$ & $\begin{array}{l}23.2 \\
9\end{array}$ \\
\hline $\begin{array}{l}\text { 1.3. Hasil Pengelolaan Kekayaan Daerah yang } \\
\text { Dipisahkan/Income of Regional Government } \\
\text { Corporate and Management of Separated Regional } \\
\text { Government Wealth }\end{array}$ & 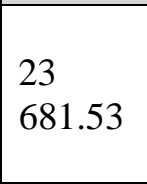 & $\begin{array}{l}28 \\
807.74\end{array}$ & $\begin{array}{l}15 \\
996.86\end{array}$ & $\begin{array}{l}- \\
44.4 \\
7\end{array}$ \\
\hline $\begin{array}{l}\text { 1.4. Lain-lain PAD yang Sah/Others Original Local } \\
\text { Gov. Revenue }\end{array}$ & \begin{tabular}{|l|}
67 \\
498.97 \\
\end{tabular} & $\begin{array}{l}154 \\
134.02\end{array}$ & $\begin{array}{l}160 \\
693.38\end{array}$ & 4.26 \\
\hline 2. Dana Perimbangan/Balanced Budget & \begin{tabular}{|l|}
855 \\
645.93 \\
\end{tabular} & $\begin{array}{l}814 \\
953.43 \\
\end{array}$ & $\begin{array}{l}1247 \\
772.42 \\
\end{array}$ & $\begin{array}{l}53.1 \\
1\end{array}$ \\
\hline $\begin{array}{l}\text { 2.1. Bagi Hasil Pajak/Bukan Pajak/Sumber Daya } \\
\text { Alam/Tax Share/non Taxes Share/Nature Resources }\end{array}$ & \begin{tabular}{|l|}
89 \\
831.37 \\
\end{tabular} & $\begin{array}{ll}68 \\
503.72 \\
\end{array}$ & $\begin{array}{l}92 \\
553.28 \\
\end{array}$ & $\begin{array}{l}35.1 \\
1\end{array}$ \\
\hline 2.2. Dana Alokasi Umum/General Alocation Funds & \begin{tabular}{|l|}
732 \\
337.06 \\
\end{tabular} & $\begin{array}{l}737 \\
833.16 \\
\end{array}$ & $\begin{array}{l}806 \\
089.54 \\
\end{array}$ & 9.25 \\
\hline $\begin{array}{l}\text { 2.3. Dana Alokasi Khusus (DAK)/Special Alocation } \\
\text { Funds }\end{array}$ & 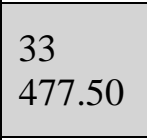 & $\begin{array}{l}8 \\
616.56\end{array}$ & $\begin{array}{l}349 \\
129.60\end{array}$ & $\begin{array}{ll}3 \\
951 . \\
84\end{array}$ \\
\hline $\begin{array}{l}\text { 3. Lain-lain Pendapatan yang Sah/Other Legal } \\
\text { Revenues }\end{array}$ & $\begin{array}{l}357 \\
215.75\end{array}$ & $\begin{array}{l}470 \\
659.92\end{array}$ & $\begin{array}{l}201 \\
530.55\end{array}$ & $\begin{array}{l}- \\
57.1 \\
8\end{array}$ \\
\hline $\begin{array}{l}\text { B. PEMBIAYAAN DAERAH/LOCAL } \\
\text { GOVERNMENT FINANCING }\end{array}$ & 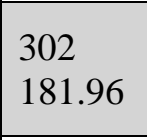 & $\begin{array}{l}301 \\
204.91\end{array}$ & $\begin{array}{l}255 \\
436.05\end{array}$ & $\begin{array}{l}- \\
15.2 \\
0\end{array}$ \\
\hline Jumlah/Total & $\begin{array}{l}2059 \\
879.34\end{array}$ & $\begin{array}{l}2214 \\
415.31\end{array}$ & $\begin{array}{l}2386 \\
362.91\end{array}$ & 7.76 \\
\hline $\begin{array}{l}\text { Sumber : Badan Pusat Statistik Kota Bogor } \\
\text { Source : BPS-Statistics of Bogor City }\end{array}$ & & & & \\
\hline
\end{tabular}

Sumber : bps bogor, 2021

Melihat dari data diatas, pendapatan di Bogor terjadinya peningkatan dan berlangsung dari tahun ke tahun berdasarkan jenis pendapatan daerahnya. Bukti tersebut menunjukkan 
bahwa pemerintah Kota Bogor berupaya untuk menekan pihak dari badan Pendapatan Daerah tertentu dan jajarannya untuk selalu memperbaiki suatu sistem yang memang ada, membangun lebih banyak relasi serta membidik sumber pendapatan lainnya. Hal ini tentu saja dapat membantu pemerintah kota Bogor untuk meningkatkan kesejahteraan rakyatnya dan terciptalah kota Bogor yang tertata rapi serta mempunyai kemungkinan untuk menjadi lokasi wisatawan mancanegara.

\section{LANDASAN TEORI}

\section{A. 1. Pengertian Pendapatan Nasional}

Pendapatan dari Nasional yakni alat dari ukur tertentu yang mana tolak ukur ini dapat digunakan untuk melakukan suatu penilaian pada kondisi ekonomi negara tertentu. Dari pendapatan nasional itu sendiri tentunya mencerminkan suatu kejadian alokasi secara efisien atau makro yang termasuk pada jangka periode tertentu. Tujuan atas semua perhitungan atas pendapatan dari nasional ini agar kita sebagai analisa atau peneliti untuk mengetahui sekaligus mendapatkan suatu gambaran mengenai bagaimana saja tahapan ekonomi yang mungkin telah diperoleh beserta nilai dari hasil output yang memang sudah diproduksi, suatu komposisi pada bagian pembelanjaan secara agregat beserta dana dari sekitar bidang khusus perekonomian dan seberapa proses tingkatan pada kemakmuran yang akan diperoleh (sukirno, 2008).

\section{Arti penting Pendapatan Nasional}

Pendapatan nasional yakni suatu proses atau tahapan yang digunakan melakukan pengukuran pada seberapa tinggi rendahnya tingkat suatu kehidupan atau kemakmuran pada suatu bangsa ataupun negara. Hal ini berkaitan dengan tingkat kehidupan serta kemajuan suatu negara yang nantinya akan ditentukan pada suatu perbandingan yang sedang terjadi antara berapa banyak jumlah pendapatan nasional dengan seberapa pada jumlah penduduk di negara itu.

\section{Penggunaan GNP dalam Pendapatan Nasional}

Penggunaan GNP dalam melakukan proses pengukuran pada pendapatan dari nasional itu kurang mampu dalam mengetahui bagaimana saja kemakmuran yang dihadapi oleh suatu bangsa yakni produk yang cenderung masuk kedalam pasar, GNP yang tidak akan menghitung seberapa nilai dari sisa beserta kejadian buruk misalnya pada bencana alam yang juga tidak akan terhitung dalam GNP serta masalah pada polusi tertentu.

\section{Faktor yang bisa saja mempengaruhi pada konsep Pendapatan suatu Nasional} yakni ;

1. Hal yang berkaitan dengan Permintaan dan suatu penawaran secara agregat

Permintaan yang terjadi secara agregat yakni suatu hal pada daftar dari keseluruhan pada produk dan jasa yang tentunya atau mungkin saja dibeli oleh bidang ataupun sektor pada perekonomian di berbagai tahapan harga. Permintaan dan penawaran agregat menunjukkan antara hubungan dari keseluruhan permintaan pada suatu barang dan jasa dan hal tersebut akan sesuai dengan tingkatan harga.

2. Konsumsi beserta proses tabungan

Konsumsi inilah bisa diartikan dengan biaya yang perlu kita bayar dan dikeluarkan untuk mendapatkan barang dan jasa pada konsep suatu perekonomian yang jangka waktunya selama 1 tahun sementara tabungan ini bisa dari bagian suatu pendapatan yang tidak akan dikeluarkan dalam hal konsumsi. 


\section{Investasi}

Dari investasi inilah semua biaya yang digunakan untuk bisa menciptakan suatu modal baru. Jadi dari persoalan investasi ini, tujuannya yakni untuk melakukan penggantian pada modal yang mengalami kesalahan atau rusak dan bisa juga memperbanyak dalam hal yang berkaitan dengan penyediaan modal yang telah ada.

\section{METODOLOGI PENELITIAN}

Dalam melakukan analisis pendapatan nasional ini, penulis menggunakan metode kuantitatif, yang mana metode ini artinya suatu proses penelitian dengan menggunakan angka sebagai alat untuk menganalisis hal yang ingin penulis ketahui. Penulis menggunakan data kuantitatif dalam analisis pendapatan nasional dikarenakan pada prosesnya dibutuhkan data berupa angka seperti hasil perhitungan dari pendapatan nasional yang terdapat pada kota bogor. Selain itu, data yang digunakan berupa data sekunder yakni didapatkan dari pihak kedua atau mencari data dari sumber seperti menganalisa jurnal-jurnal terkait, artikel, ataupun berita. Dalam proses analisa inilah, penulis menganalisa, mengumpulkan data dan melakukan perhitungan yang nantinya akan menarik kesimpulan tentang bagaimana saja dan apa saja pendapatan nasional yang terjadi pada kota bogor, serta apakah ada dampak baik atau buruk dengan nilai dari perhitungan tersebut. Untuk mendapatkan data mengenai pendapatan suatu kota, penulis mencari di sumber-sumber yang dapat dipercaya misalnya dari website badan pusat statistik langsung, dimana penulis percaya data-data di website tersebut merupakan datadata yang kredibel mengenai pendapatan suatu kota di Indonesia. Proses dari pengumpulan data dilakukan dengan meneliti dan memeriksa website yang penulis dapat, sehingga penulis memastikan data yang dimuat dalam penelitian ini adalah data asli dan dapat dipercaya sumbernya. Proses selanjutnya adalah meneliti data yang telah penulis kumpulkan apakah tingkat pendapatannya naik maupun turun. Data yang sudah penulis kumpulkan akan dimuat kedalam jurnal dalam bentuk tabel atau tulisan.

\section{HASIL PENELITIAN}

Berdasarkan hasil penelitian penulis, ada 3 hal utama dalam komposisi pendapatan daerah, hal-hal tersebut seperti pendapatan dari asli daerah tertentu, dana pada perimbangan, dan lain-lain pendapatan daerah yang sah. Penulis membuat kesimpulan bahwa pendapatan asli daerah kota bogor mengalami peningkatan dari tahun ke tahun. Di tahun 2019, penerimaan pajak kota bogor berjumlah Rp 687 miliar lebih tinggi dari yang ditargetkan yaitu sebesar Rp 620 miliar sedangkan di tahun 2020 di targetkan penerimaan pajak kota bogor berjumlah Rp 733 miliar dan total PAD adalah sebesar Rp 1,08 triliun. Berdasarkan data sensus penduduk miskin di Kota Bogor, persentase kemiskinan penduduk Bogor meningkat di tahun 2020, penulis mempercayai bahwa ini adalah efek suatu pandemi selama terjadinya covid-19 yang sekarang sedang melanda seluruh dunia. Alasan kuat lainnya adalah, data sensus penduduk miskin Kota Bogor dari tahun 20102019 selalu mengalami penurunan persentase yang cukup signifikan. Peningkatan yang terjadi di tahun 2014-2015, berhasil diturunkan oleh pemerintah Kota Bogor. Meskipun terjadi peningkatan persentase penduduk miskin di kota Bogor, pemerintah kota Bogor tetap berupaya keras untuk mencapai PAD yang sudah disahkan. Pemerintah kota Bogor menggelar razia pajak kendaraan besar-besaran dan dari hasil razia tersebut pajak kendaraan bermotor yang tertagih sebesar Rp 415 miliar. Hal ini tentu saja merupakan sebuah kabar baik mengingat APD yang ditargetkan adalah sebesar Rp 1,08 triliun. Namun, hal ini juga berarti masih banyak masyarakat kota Bogor yang tidak taat pajak. 
PEMERINTAH KOTA BOGOR

RINGKASAN APBD

TAHUN ANGGARAN 2020

\begin{tabular}{|c|c|c|}
\hline No Urut & Uraian & Jumlah \\
\hline 1 & 2 & 3 \\
\hline 1. & PENDAPATAN & \\
\hline 1.1 & PENDAPATAN ASLI DAERAH & \\
\hline 1.1.1 & Pendapatan Pajak Daerah & $733.276 .508 .019,00$ \\
\hline 1.1 .2 & Hasil Retribusi Daerah & $60.828 .518 .400,00$ \\
\hline 1.1 .3 & Hasil Pengelolaan Kekayaan Daerah yang Dipisahkan & $36.044 .034 .570,00$ \\
\hline \multirow[t]{2}{*}{1.1 .4} & Lain-lain Pendapatan Asli Daerah yang Sah & $253.263 .237 .231,00$ \\
\hline & JUMLAH PENDAPATAN ASLI DAERAH & $1.083 .412 .298 .220,00$ \\
\hline 1.2 & DANA PERIMBANGAN & \\
\hline 1.2 .1 & Bagi Hasil Pajak/Bagi Hasil Bukan Pajak & $81.407 .390 .000,00$ \\
\hline 1.2 .2 & Dana Alokasi Umum & $850.811 .547 .000,00$ \\
\hline \multirow[t]{2}{*}{1.2 .3} & Dana Alokasi Khusus & $122.397 .055 .000,00$ \\
\hline & JUMLAH DANA PERIMBANGAN & $1.054 .615 .992 .000,00$ \\
\hline 1.3 & LAIN-LAIN PENDAPATAN DAERAH YANG SAH & \\
\hline 1.3.1 & Pendapatan Hibah & $396.000 .000,00$ \\
\hline 1.3 .2 & Dana Bagi Hasil Pajak dari Provinsi dan Pemerintah Daerah Lainnya & $281.156 .043 .969,00$ \\
\hline \multirow[t]{3}{*}{1.3 .3} & Dana Penyesuaian dan Otonomi Khusus & $14.764 .283 .000,00$ \\
\hline & JUMLAH LAIN-LAIN PENDAPATAN DAERAH YANG SAH & $296.316 .326 .969,00$ \\
\hline & JUMLAH PENDAPATAN & $2.434 .344 .617 .189,00$ \\
\hline
\end{tabular}

Gambar 4.1 Ringkasan APD Kota Bogor

\section{KESIMPULAN}

Melihat dari hasil kinerja pemerintah Kota Bogor, kemungkinan untuk mencapai PAD yang sudah disahkan tersebut sangat mungkin tercapai. Pemerintah kota Bogor bersikap tegas mengenai pajak masyarakat kotanya sehingga terciptalah masyarakat yang taat pajak. Pajak negara akan digunakan untuk perkembangan negara. Rekomendasi yang sesuai dan hal yang perlu diperhatikan kedepannya yakni membantu untuk melakukan tahap suatu alokasi peluang-peluang transfer suatu daerah dari pusat dengan tujuan agar bisa mentransfer dana dari pusat untuk melakukan kegiatan pembangunan di wilayah bogor. Selain itu, keuntungan yang bisa kita dapatkan cenderung bisa meningkatkan ekonomi dan kesejahteraan pada masyarakat bogor.

\section{UCAPAN TERIMA KASIH}

Pertama-tama kami ucapkan puji dan syukur kepada tuhan yang maha esa, karena berkatnya lah kami dapat menyelesaikan jurnal ini dengan keadaan sehat. Kami mengucapkan terima kasih kepada dosen kami yang telah membimbing kami, orang tua kami yang telah menjaga dan membesarkan kami hingga ke bangku mahasiswa, serta teman-teman kami yang turut berkontribusi dalam penyelesaian jurnal ini. Selain itu, kami juga berterima kasih kepada tim Jesya yang telah bersedia meluangkan waktu untuk menindak jurnal kami, serta kesempatan yang telah diberikan kepada kami.

\section{DAFTAR PUSTAKA}


Badan Pusat Statistik. (2018). Realisasi Penerimaan Pemerintah Kota Bogor Menurut Jenis Pendapatan, 2014-2016.

https://bogorkota.bps.go.id/statictable/2018/05/23/148/realisasi-penerimaanpemerintah-kota-bogor-menurut-jenis-pendapatan-2014-2016.html

RAKYAT, D. P., \& INDONESIA, R. (2021). Pandemi Covid-19 Berdampak pada Pendapatan Daerah. https://www.dpr.go.id/berita/detail/id/31692/t/Pandemi+Covid19+Berdampak+pada+Pendapatan+Daerah

Eka Sri Apriliana. (2020). Upaya Peningkatan Pendapatan Nasional di Tengah Wabah Virus Corona Perspektif Ekonomi Islam. Al-Iqtishadiyah, 6, 19-28.

Hamimah, Z. (2020). PENGARUH KINERJA KEUANGAN DAERAH TERHADAP IPM KABUPATEN/KOTA DI JAWA BARAT. 1.

Kotabogor.go.id. (2020). Bima Arya Minta Bapenda “Agresif” Capai Target PAD 2020. https://kotabogor.go.id/index.php/show_post/detail/13812

kotabogor.go.id. (2016). Pemerintah Kota Bogor. 29 Desember 2016. http://kotabogor.go.id/

Ayumi, L. (2021). Simak Profil Pajak Kabupaten Berpenduduk Terbanyak di Indonesia. https://news.ddtc.co.id/simak-profil-pajak-kabupaten-berpenduduk-terbanyak-diindonesia-26834

Syauqi, M., Siregar, H., \& Syaukat, Y. (2017). Strategy Increased Efficiency and Effectiveness of Bogor City Government Finance Performance in Managing the Budgetary of Regional Revenue and Expenditure PENDAHULUAN Paradigma pengelolaan keuangan daerah telah mengalami perubahan yang sangat mendasar sej. 9, 1-16.

Prasetya, E. R. (2018). Analisis Sektor Unggulan Perekonomian Di Kabupaten Bogor. Scientific Journal of Reflection, 1(4), 1-10. https://doi.org/10.5281/zenodo.1436986

Statistik, B. P. (2021). Persentase Penduduk Miskin (Persen), 2018-2020. https://bogorkota.bps.go.id/indicator/23/123/1/persentase-penduduk-miskin-.html

Haryudi. (2020). Pemkot Bogor Gelar Razia Pajak Kendaraan Besar-besaran. https://metro.sindonews.com/berita/1531081/171/pemkot-bogor-gelar-raziapajak-kendaraan-besar-besaran

The Ministry of Finance of The Republic of Indonesia. (2017). Sumary of the Local Government Budgets. 20. 